\title{
Genotypic variation of forage maize (Zea mays L.) hybrids to sources of nitrogenous fertilizer under non-saline and saline conditions
}

\author{
Muhammad Ibrahim ${ }^{1}$, Muhammad $\mathrm{Jan}^{2 *}$, Muhammad Mudassar \\ Maqbool $^{1}$, BushraTariq ${ }^{1}$, Mubashar Nadeem ${ }^{3}$, Abdul Rauf ${ }^{4}$ and Anam \\ Noreen Abbas $^{5}$ \\ 1. Department of Agronomy Faculty of Agricultural Sciences, Ghazi University, Dera Ghazi Khan, Pakistan \\ 2. Centre of Excellence for Olive Research and Training (EFFORT), Barani Agricultural Research Institute, \\ Chakwal, Pakistan \\ 3. Departments of Agronomy, College of Agriculture, University of Sargodha, Sargodha, Pakistan \\ 4. Agriculture Officer (Field) Dera Ghazi Khan, Pakistan \\ 5. Department of Entomology, University of Agriculture, Faisalabad, Pakistan \\ *Corresponding author's email: mjanleghari@gmail.com \\ Citation \\ Muhammad Ibrahim, Muhammad Jan, Muhammad Mudassar Maqbool, BushraTariq, Mubashar Nadeem, Abdul \\ Rauf and Anam Noreen Abbas. Genotypic variation of forage maize (Zea mays L.) hybrids to sources of \\ nitrogenous fertilizer under non-saline and saline conditions. Pure and Applied Biology. Vol. 10, Issue 4, pp1388- \\ 1397. http://dx.doi.org/10.19045/bspab.2021.100144
}

\begin{tabular}{llll}
\hline \hline Received: 26/01/2021 & Revised: 26/03/2021 & Accepted: 04/04/2021 & Online First: 22/04/2021
\end{tabular}

\section{Abstract}

Water shortage and good quality irrigation water are the main alarming issues for forage production of maize crop in the area of arid and semiarid which enforcing the farmers to utilize municipal irrigation and recycled underground brackish water. These constraints reducing the forage yield and resulting into low forage production due to imbalance fertilizer, salinity and solicitation. Nitrogen (N) application is beneficial for the crops in the accordance of its role in crop productivity and nutrient use efficiency. The current study was conducted to study nitrogenous fertilizers role on maize growth under saline conditions. Nitrogenous fertilizers application increased the plant growth parameters in the term of physical para meters like fresh and dry biomass, plant height $(\mathrm{cm})$, leaf area per plant $(\mathrm{cm})$, number of leaves per plant and crude protein $(\%)$ under saline conditions. Nitrogen sources application increased the concentration of nitrate $\left(\mathrm{NO}_{3}\right)$, ammonium $\left(\mathrm{NH}_{4}\right)$, potassium $(\mathrm{K}), \mathrm{K}: \mathrm{Na}$ ratio and decreased sodium (Na), under saline condition. A significant difference was observed in all three maize hybrids while comparing the genotypic performance, the maize hybrid FH-949 showed the considerable increase in all observed parameters as compared toFH-9 22 and Pak-Afgoe which showed a significant reduction in term of all growth parameter under saline conditions.

Keywords: Ammonium; Hybrids; Imbalance fertilizers; K: Na ratio; Nitrate

\section{Introduction}

Salinity is becoming one of the alarming issue due to sudden inverse in climate change which reducing the plant yield as well as development [1, 2]. In world the extent of salt affected soil is $20 \%$ and in which $50 \%$ of irrigated land is deteriorated just only due to salinity [3]. The main contributing factors is shortage of irrigation water in dry as well as irrigated areas which 
enforcing the formers to utilize municipal or brackish water for irrigation purpose [4]. Maize crop is mostly sensitive against salinity at early heading stage which ultimately reduces the forage production as well as quality. For fodder and good forage purpose it is important to harvest crop at two to three weeks before grain maturity. It is also considered as an important raw material for multi manufactured goods and food grain for animals [5].

In agriculture, maize crop contributes 0.4 percent to Gross Domestic Product (GDP) but during the previous year's area maize cultivation decreased $3.30 \%$ due to reduction in sown area [6]. It is edible cereal forage which consist of 29.9-31.38\% crude fiber, $8.62-10.32 \%$ crude protein, $8.45-9.24 \%$ total ash and $1.27-1.35 \%$ ether extractable fats [7]. In Pakistan, different biotic and abiotic factors are responsible for low production which create problem during lifecycle and genetic material secondly the miss management in balance fertilizer and in irrigation application. So the main constraints for maize yield reduction in Pakistan are imbalance fertilizer application, lack of high yielding genotypes of forage maize, and salinity which influencing the forage productivity of maize crop [8].

Maize crop have a significant forage importance, in earlier duration many of genotypes were introduced and to maximize the production use of these high yielding are best to fulfill the increasing demand of livestock food [7, 9]. The production as well as quality of these genotypes mostly affected due to the ecological factors. It is important to select such type of cultivars by adopting short gun approaches like the suitable nutrient source application under salt stress conditions [10].

Among the essential nutrients, Nitrogen $(\mathrm{N})$ is one of the important nutrient which increase the crop quality and yield, protein contents and seed quality. Nitrogen application also increase the photosynthetic rate and improve the leaf area and enhance the vegetative growth $[11,12]$. The higher dose of $\mathrm{N}$ results into ecological contamination so its proper source, its form and doses are needed to consider to prevent the risks from human and soil health [13]. Plants absorb $\mathrm{N}$ in the form of anion $\left(\mathrm{NO}_{3}{ }^{-}\right.$ ) and cation $\left(\mathrm{NH}_{4}{ }^{+}\right)$which also affected by $\mathrm{pH}$ of the root zone (Cheema et al. 2010). The ammonium $\left(\mathrm{NH}_{4}{ }^{+}\right)$uptake in plants reduced $\mathrm{pH}$ of root zone through releasing proton $\left(\mathrm{H}^{+}\right)$which enhance the concentration of $\left(\mathrm{NH}_{4}{ }^{+}\right)$in vacuole of cell [14].

Nitrate form is less harmful can be accumulated into shoot and other parts. The absorption of $\mathrm{N}$ sources effects the $\mathrm{N}$ type given to plants also depends on the chemical composition of plants to control the relative ions uptake $[15,16]$. The plants which uptake more NO3 that will reduce the uptake of metals as compared to those provided with $\mathrm{NH}_{4}{ }^{+}$[17-19].

The applied form of $\mathrm{N}$ a key role on plant vegetative and reproductive growth which also dependent on growing site, fertilizer dose and crop specie. Keeping in view the $\mathrm{N}$ role in plant growth under saline condition, the current study conducted with the objectives to evaluate the comparative effects of $\mathrm{NO}_{3}-\mathrm{N}$ and $\mathrm{NH}_{4}-\mathrm{N}$ and to study the comparative performance of maize hybrids under saline condition.

\section{Material and Methods \\ Experimental conditions and plant material}

The experiment was conducted in the research area of Agronomy department. Soil samples were analyzed in the laboratory for physico chemical analysis. Soils samples ECe and $\mathrm{pH}$ were measured by using EC meter (DDS -307A) and $\mathrm{pH}$ meter and cation exchange capacity (CE C) was measured by using ammonium acetate method wet oxidation method used for the measurement of organic matter contents. The soil analysis before the experiment conducting are given inn (Table 1). Salinity was artificially developed into pots by using the method of U.S. Salinity Lab Staff [18]. The levels of nitrogenous fertilizers 
were applied by using ammonium sulphate (as a source of $\mathrm{NH}_{4}$ ). and calcium nitrate (as a source of $\mathrm{NO}_{3}$ ).

There were six treatment i-e $\mathrm{T}_{1}$ : controlT $_{2}: \quad \mathrm{EC}=10.00 \mathrm{dS} \quad \mathrm{m}^{-1}, \quad \mathrm{~T}_{3}$ : ammonium sulphate ( $75 \mathrm{mg} \mathrm{kg}^{-1}$ soil), $\mathrm{T}_{4}$ : calcium nitrate (75.00mgper $\mathrm{kg}$ soil), $\mathrm{T}_{5}$ : ammonium sulphate $+\mathrm{EC}=10.00 \mathrm{dSm}^{-1}$, $\mathrm{T}_{6}$ : calcium nitrate $+\mathrm{EC}=10.00 \mathrm{dS} \mathrm{m}{ }^{-1}$ with triplicates. All the treatments arranged factorial with three replications. Three maize hybrids i-e. FH-949, FH-922, and Pak Afgoe sown for this experiment. Seed of all maize hybrids imported from AARI, Faisalabad. After sieving of soil $20 \mathrm{~kg}$ pots were filled with sieved soil. The recommended dose of NP $\mathrm{K}$ was thoroughly mixed into the soil. The first dose of $\mathrm{N}$, all $\mathrm{P}$ and $\mathrm{K}$ were applied at the pot filling Maize seeds were soaked distill water, five seeds were sown in each pot. Plants were thinned to maintain two plants in each pot. For maintain the field capacity, pots were irrigated with distilled water to for more fifty days.

\section{Plant parameters}

After the duration of 45 days, plants were harvested, and left for sun drying. Samples were oven dried to constant weight and weighed with a spring balance and yield per plant was recorded. After harvesting, shoots samples were oven dried at $70^{\circ} \mathrm{C}$ to obtain a constant weight. A homogenous portion of finely ground shoots samples were passed through 40-mesh sieve and samples were digested in a di-acid mixture which was prepared by mixing the ratio of $\mathrm{HNO}_{3}: \mathrm{H} \mathrm{ClO}_{4}(2: 1)$ respectively [20].

The sample of $0.5 \mathrm{~g}$ dry plant material added into a 100-mLdigestion tube. The plant material was digested in the mixture of sulfuric acid and hydrogen per oxide. Leaf $\mathrm{NO}_{3}-\mathrm{N}$ concentration was determined by the method as suggested by [21]. For the determination of $\mathrm{NH}_{4}-\mathrm{N}$, plant samples were digested in the mixture of $\mathrm{K}_{2} \mathrm{SO}_{4}$ and $\mathrm{HgO}$ as acatalyst and it was determined by the colorimetric method using autoanalyser system. Ammonium in the digested plant samples was determined by spectro photo meter (Shimadzu, UV - 1201, Kyoto, Japan). The absorbance was read in spectro photo meter at650 $\mathrm{nm}$. The concentration of $\mathrm{K}$ and $\mathrm{Na}$ were determined by using flame photo meter (Model410, Thermo Electron Limited, Cambridge, UK) respectively.

\section{Statistical analysis}

The mean data regarding shoot dry matter and mineral content were analyzed statistically by using Statistix 9®. Least significance difference (LSD) test used for mean separation. The variations of the data were expressed as standard deviation and significance of the data was calculated at the $\mathrm{p}<0.05$ [22].

Table 1. Soil analysis used for experiment

\begin{tabular}{|c|c|c|}
\hline Soil Characteristics & Values & Units \\
\hline Nitrogen & 10 & $\mathrm{mg} \mathrm{kg}^{-1}$ \\
\hline Organic matter & 0.90 & $\%$ \\
\hline SAR & 3.45 & $\%$ \\
\hline Soil Texture & Clayey soil & \\
\hline Saturation percentage & 60.00 & $\left.\mathrm{dS} \mathrm{mol} \mathrm{L}^{-1}\right)^{1 / 2}$ \\
\hline $\mathrm{pH}_{\mathrm{s}}$ & 7.50 & \\
\hline $\mathrm{EC}_{\mathrm{e}}$ & 1.90 & \\
\hline
\end{tabular}

\section{Results and Discussion}

Plant height $\left(\mathrm{cm}^{2}\right)$ and number of leaves per plant

According to forage importance point of plant height and number of leaves per plant are considered one of the important parameter. Maize hybrid FH-949 produced maximum numbers of leaves per plant (9.49) and plant height $(144.00 \mathrm{~cm})$ while minimum leaves (7.30) and plant height 
(92.33 cm) was observed in Pak-Afgo under non-saline conditions (Fig. 1).

Plant height and number of leaves per plant reduced adversely under saline conditions. Maximum plant height $(67.33 \mathrm{~cm})$ was observed in FH- 949in the treatment where ammonical form of $\mathrm{N}$ while minimum plant height $(55.60 \mathrm{~cm})$ was observed in PakAfgoe where no $\mathrm{N}$ was applied. So the genotype FH-949 performed best under both of the conditions as compared to FH922 and Pak-Afgoe.

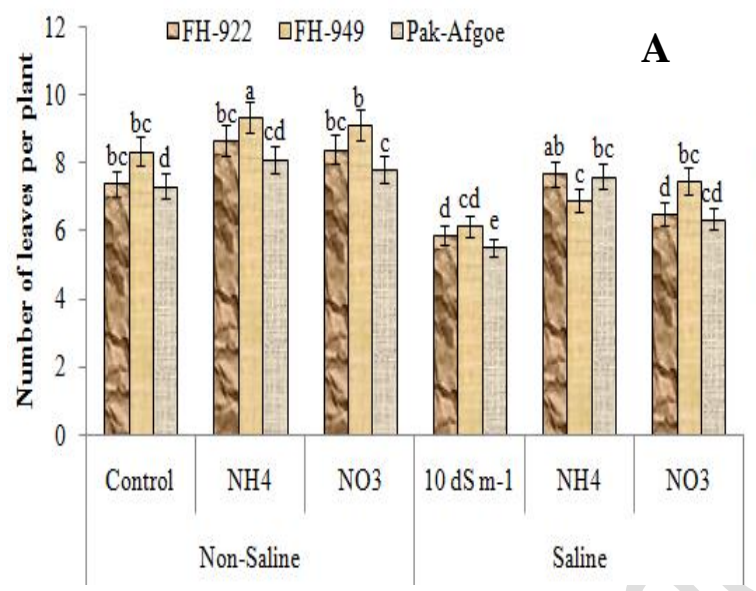

Application of $\mathrm{N}$ increased the plan height and number of leaves under non saline conditions which results due to higher fertilizer levels which ultimately facilitate the diffusion and increased nutrient availability. This increase in plant height also observed by some other researchers [23-26]. Some other researchers [27-29] also reported that it might be due to genetic variations and easily facilitation of nutrient in root zone which ultimately improve plant growth in term of an increase in number of leaves and plant height.

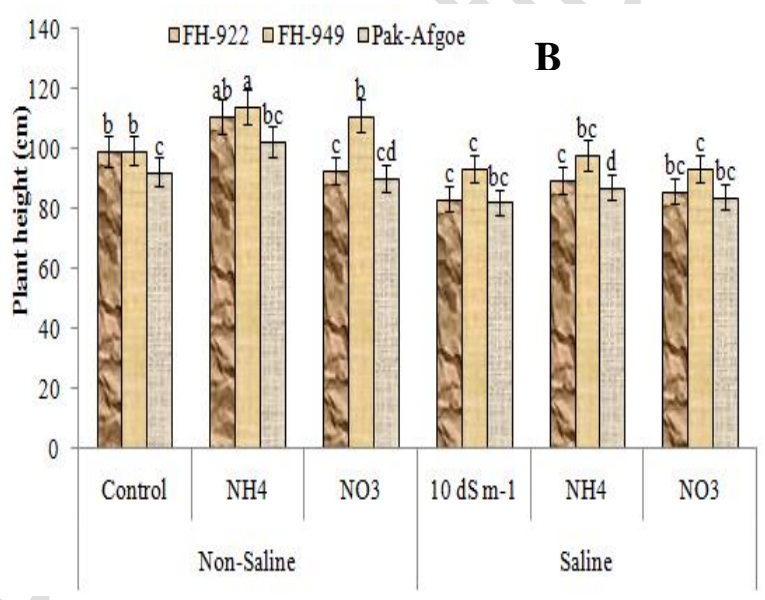

Figure 1. Effect of $\mathrm{NO}_{3}-\mathrm{N}$ and $\mathrm{NH}_{4}-\mathrm{Non} \mathrm{A}$ ) leaves per plant and $\mathrm{B}$ ) plant height of maize hybrids

\section{Leaf Area (cm) and Crude protein (\%)}

The application of nitrogenous fertilizers increased the leaf area of all maize hybrids under non-saline conditions. Among the maize genotype maximum leaf area (80.86 $\mathrm{cm})$ and crude protein $(9.02 \%)$ was observed in FH-949followed by FH922while in Pak-Afgoe minimum leaf area $(70.00 \mathrm{~cm})$ and crude protein $(6.76 \%)$ was observed (Fig. 2). Application of $\mathrm{NO}_{3}-\mathrm{N}$ increased the leaf area and crude protein as compared to applied $\mathrm{NH}_{4}-\mathrm{Nform}$.

To estimate the quality of forage contents of crude protein are very important. The quality of forage is considered best when crude protein contents existing in higher quantity in forage composition. Salinity stress adversely reduced the plant growth as a result of physiological dehydration which thick the chlorophyll contents and decreased leaf area. In case of saline environment, maximum leaf area (67.33 $\mathrm{cm})$ was observed in FH-949through the application of $\mathrm{NH}_{4}$-Nand minimum leaf area $(55.60 \mathrm{~cm})$ was observed in Pak- Afgoe in the treatment where no $\mathrm{N}$ was applied.

The response of maize hybrids against nitrogenous fertilizers was different as a result of variation in genetic potential. Difference in crude protein of maize hybrids also reported by $[29,30]$ reported contradict as they found non-significant differences between hybrids of sorghum. Plants which were fertilized with $\mathrm{NH}_{4}-\mathrm{N}$ under non-saline condition might be due to the uptake of more nitrogen resulting in more nitrogen in plants. Similar findings as observed in current study as observed by [31] in maize. In case of leaf area similar observation were also observed by $[32,33]$ 
they reported that the leaf area increased in maize and millet as a result of nitrogenous fertilizer application.
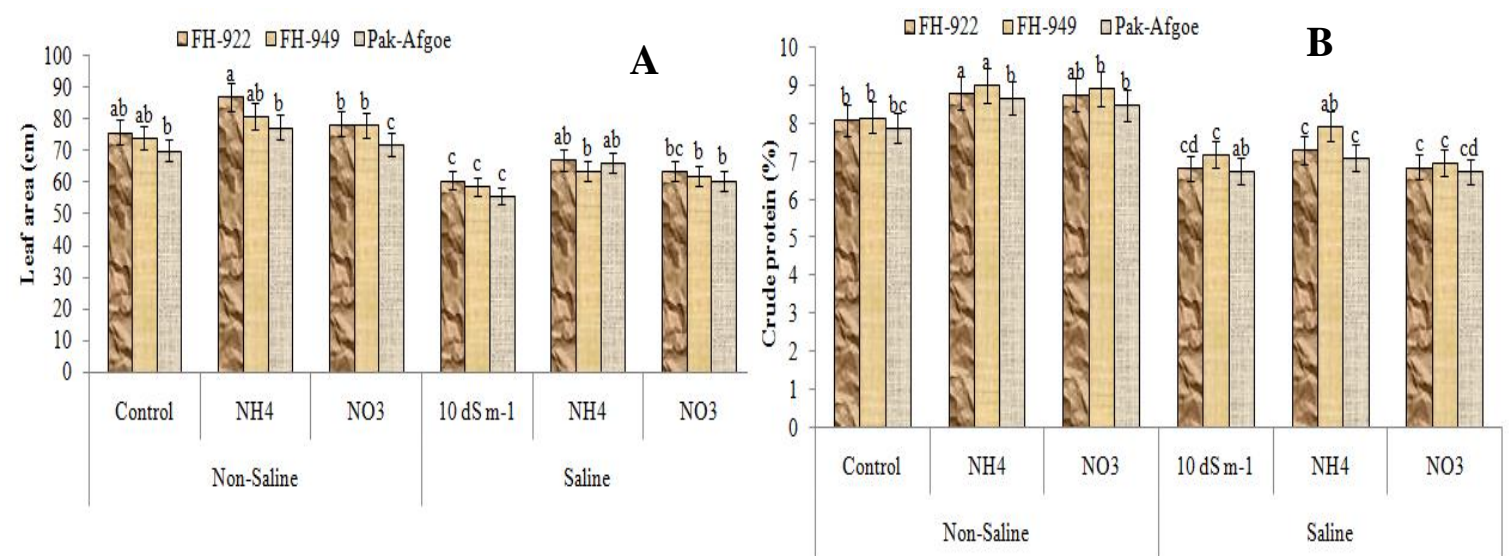

Figure 2. Effect of $\mathrm{NO}_{3}-\mathrm{N}$ and $\left.\mathrm{NH}_{4}-\mathrm{Non} \mathrm{A}\right)$ leaf area $(\mathrm{cm})$ and $\left.\mathrm{B}\right)$ crude protein $(\%)$ of maize hybrids

\section{Fresh and dry biomass per plant (g)}

Production of green forage is also dependent on the fresh biomass production. The highest (199.05g) fresh biomass and dry biomass $(84.59 \mathrm{~g})$ was observed in $\mathrm{FH}$ 949 through $\mathrm{NH}_{4}$ form of $\mathrm{N}$ application while "Pak-Afgoe" maize genotype produced minimum fresh $(143 \mathrm{~g})$ and dry biomass $(81.00 \mathrm{~g})$ under non-saline condition (Fig. 3). The highest fresh and dry biomass were (140.79 g) and (60.45 g) respectively while lowest fresh and dry weight were (108.28 g) and (43.40g) which was observed in Pak-Afgoe under saline conditions. So the application of $\mathrm{NH}_{4}$ enhance the fresh and dry biomass as compared to $\mathrm{NO}_{3}-\mathrm{N}$ form.

The application of $\mathrm{N}$ increased the chlorophyll contents and facilitate the photosynthesis process also have a key role in protein contents all these improve the plant growth and development and increase the biomass of maize crop. Similar findings in accordance to maize and sorghum cultivars. It has been confirmed by the previous findings of $[29,30,34,35]$ they reported that maize plant fresh weight enhanced with the application of ammonium sulphate as a source of nitrogen fertilizer under normal and salt stressed conditions.
The increase in plant fresh and dry biomass trough the NH4-N application results actually due to net photosynthesis, plant water potential and improvement in plant water use efficiency. Similar findings were also reported by some other researchers $[26,27,36]$ as they reported that application of $\mathrm{N}$ in the form of ammonium fertilizer increased the plant growth as it has key role in soil medium acidification and other nutrient availability which ultimately results into more forage production.

\section{Ionic contents (m mol g-1 dry wt)}

Salt stress causes osmotic effect which limits the nutrients and water uptake because of higher concentration $\mathrm{f} \mathrm{Na}$ in soil solution. The highest content of $\mathrm{Na}$ under saline condition (Fig. 4). Maximum sodium content $(396.50 \mathrm{mM})$ was observed in Pak afgoee genotype and while maximum $\mathrm{K}$ content $(179.78 \mathrm{mM})$ was observed in $\mathrm{FH}-$ 922 maize genotype through the application of $\mathrm{NH}_{4}-\mathrm{N}$. In contrast, lowest sodium contents $(325.55 \mathrm{mM})$ and maximum $\mathrm{K}$ (198.56 mM) was observed in FH-949. Comparing the $\mathrm{N}$ sources impact it was observed that the application of $\mathrm{NH}_{4}-\mathrm{N}$ application increased the $\mathrm{K}$ concentration and reduced the $\mathrm{Na}$ concentration as compared to $\mathrm{NO}_{3}-\mathrm{N}$ form. 

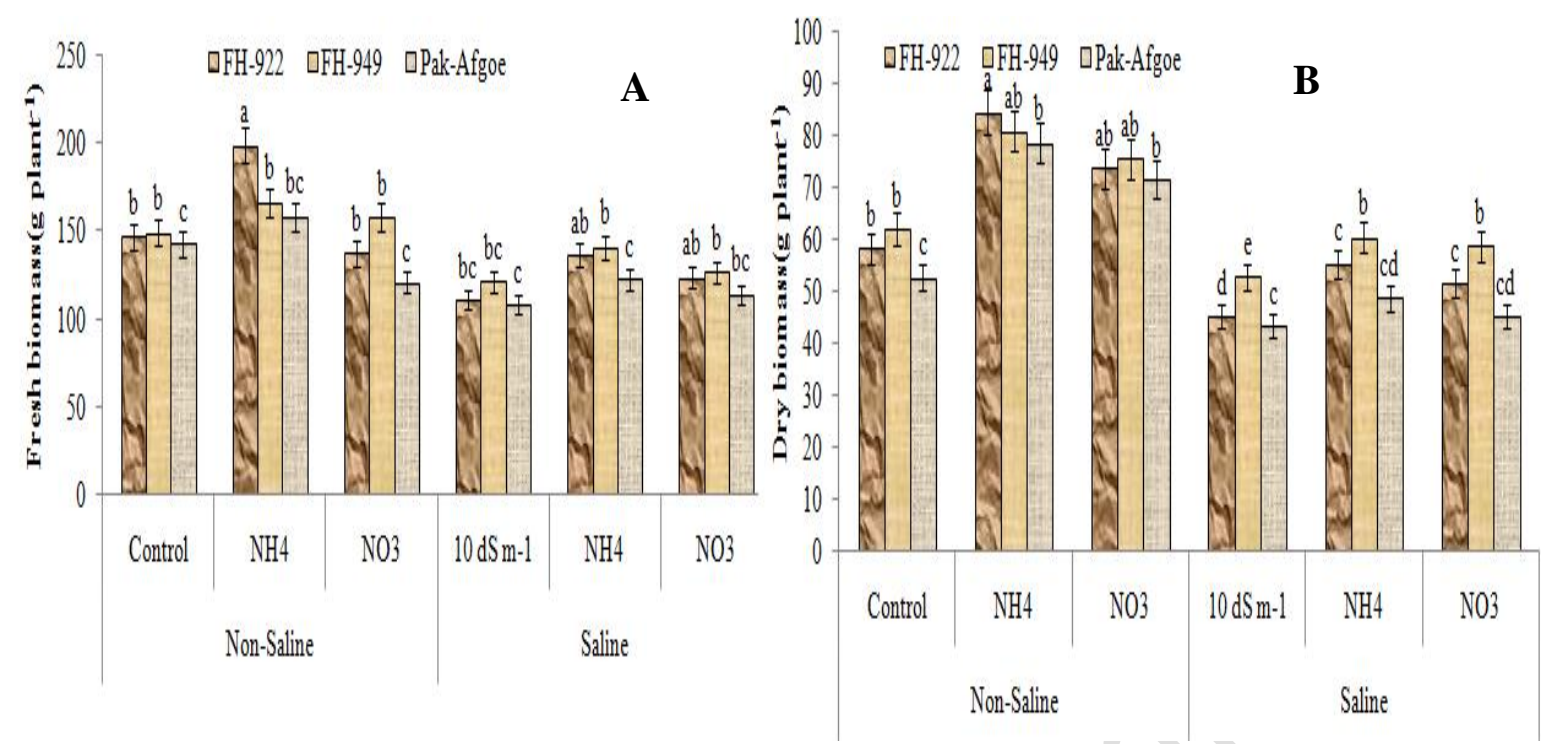

Figure 3. Effect of NO3-N and $\mathrm{NH}_{4}-\mathrm{N}$ on $\mathrm{A}$ ) fresh biomass (g) B) dry biomass (g) of maize hybrids
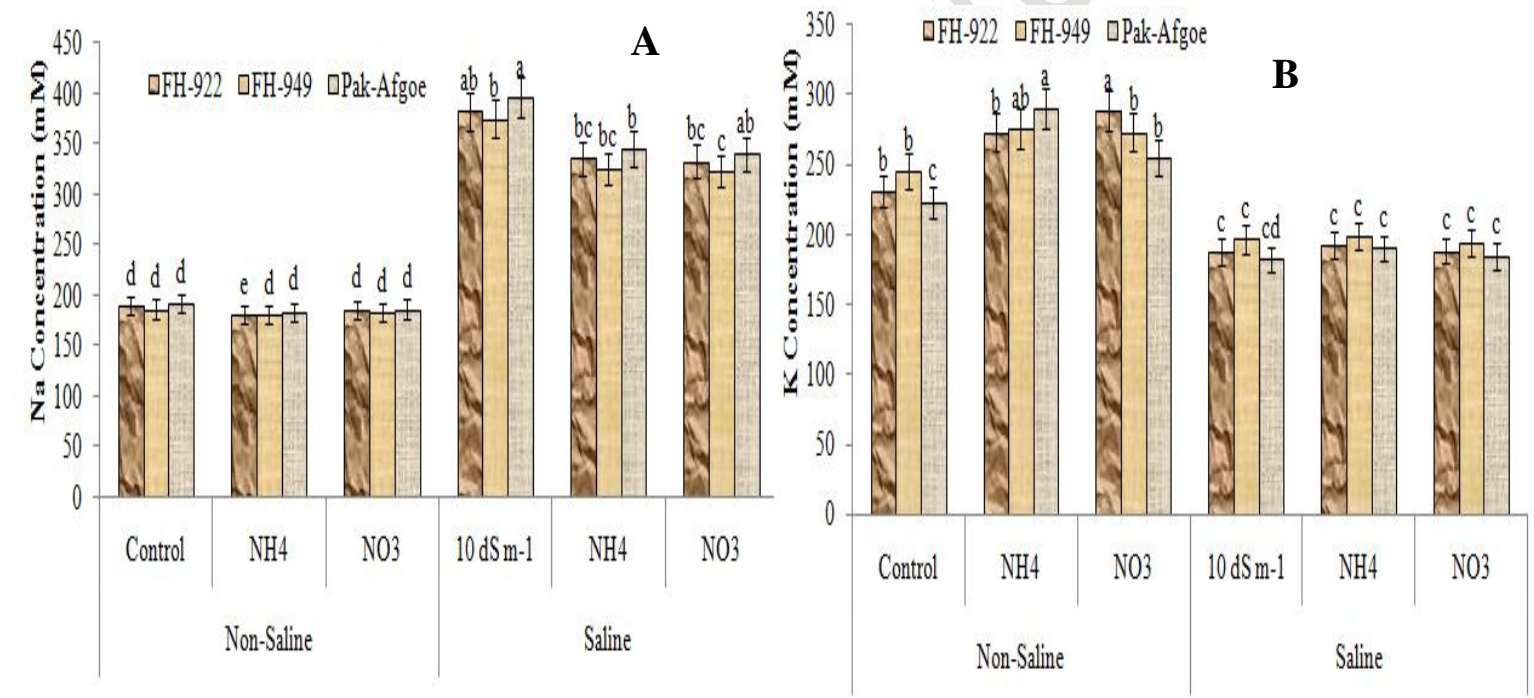

Figure 4. Effect of $\mathrm{NO}_{3}-\mathrm{Nand} \mathrm{NH}_{4}-\mathrm{N}$ on A) sodium concentration B) potassium concentration of maize hybrids

Nitrogenous fertilizer application increases the stomatal conductance and ultimately net photosynthetic process. An increase in $\mathrm{K}^{+}$ concentration and suppressing of $\mathrm{Na}^{+}$also argued by other researchers [37, 38]. In case of salt stressed conditions, the excess amount of toxic $\mathrm{Na}$ having osmotic effect as well as oxidative damage of maize causing stunted growth and development. Similar findings were also reported by some other researchers [26, 39-43].
A similar trend as observed in case of $\mathrm{K}: \mathrm{Na}$ ratio as observed for $\mathrm{K}$ concentration under non-saline conditions but in the saline conditions. $\mathrm{K}: \mathrm{Na}$ ratio and $\mathrm{K}$ concentration decreased asa result of higher concentration of $\mathrm{Na}$ under saline condition. Application of $\mathrm{NH}_{4}-\mathrm{N}$ increased $\mathrm{K}: \mathrm{Na}$ ratio in $\mathrm{FH}-$ 949while minimum $\mathrm{K}: \mathrm{Na}$ ratio was observed in Pak-Afgoee under salt stressed conditions (Fig. 5). The application of $\mathrm{NH}_{4}$ $-\mathrm{N}$ increased the $\mathrm{K}: \mathrm{Na}$ ratio and reduced 
the $\mathrm{Na}$ concentration as compared to $\mathrm{NO}_{3}-$ $\mathrm{N}$ form. Similar observation was also observed by researchers $[41,42]$ they observed that variable response of $\mathrm{K}: \mathrm{Na}$ ratio of different fertilizers applications in maize crop under saline exist due to antagonistic effect of $\mathrm{K}$ and $\mathrm{Na}$. The application of $\mathrm{N}$ in the form of NH4-N fertilizers increased the $\mathrm{K}$ and $\mathrm{K}$ : $\mathrm{Na}$ ratio which was also reported by other researchers [43-45] in case of maize crop.

\section{Leaf $\mathrm{NH}_{4}$ and $\mathrm{NO}_{3}$ concentration}

The $\mathrm{NO}_{3}$ concentration increased through Nitrate-N application while application of $\mathrm{NH}_{4}-\mathrm{N}$ increased $\mathrm{NH}_{4}$ contents in nonsaline and saline conditions. The highest $\mathrm{NO}_{3}$ (455.67\%) and $\mathrm{NH}_{4}$ concentration $(56.66 \%)$ was observed in FH-949 through the $\mathrm{N}$ sources application respectively while minimum $\mathrm{NO}_{3}(319.33 \%)$ and $\mathrm{NH}_{4}$ concentration $(23.33 \%)$ was observed in Pak-Afgoee under salt stressed conditions (Fig. 6). Comparing the genotypic performance, FH-949 uptake maximum $\mathrm{NO}_{3}$ and $\mathrm{NH}_{4}$ concentration followed by FH-922 while minimum $\mathrm{NO}_{3}$ and $\mathrm{NH}_{4}$ concentration was observed in Pak-Afgoee maize hybrids.

Nitrate form of nutrition is not so much effective as compared to $\mathrm{NH}_{4}$ and mixing of $\mathrm{NO}_{3}$ and $\mathrm{NH}_{4}$ form of fertilizer under saline conditions while comparing the individual application NH4-N form is most beneficial for maize crop $[46,47]$ also reported similar arguments while working on maize under normal and salt application. Similar findings were also reported by $[25,48,49]$.

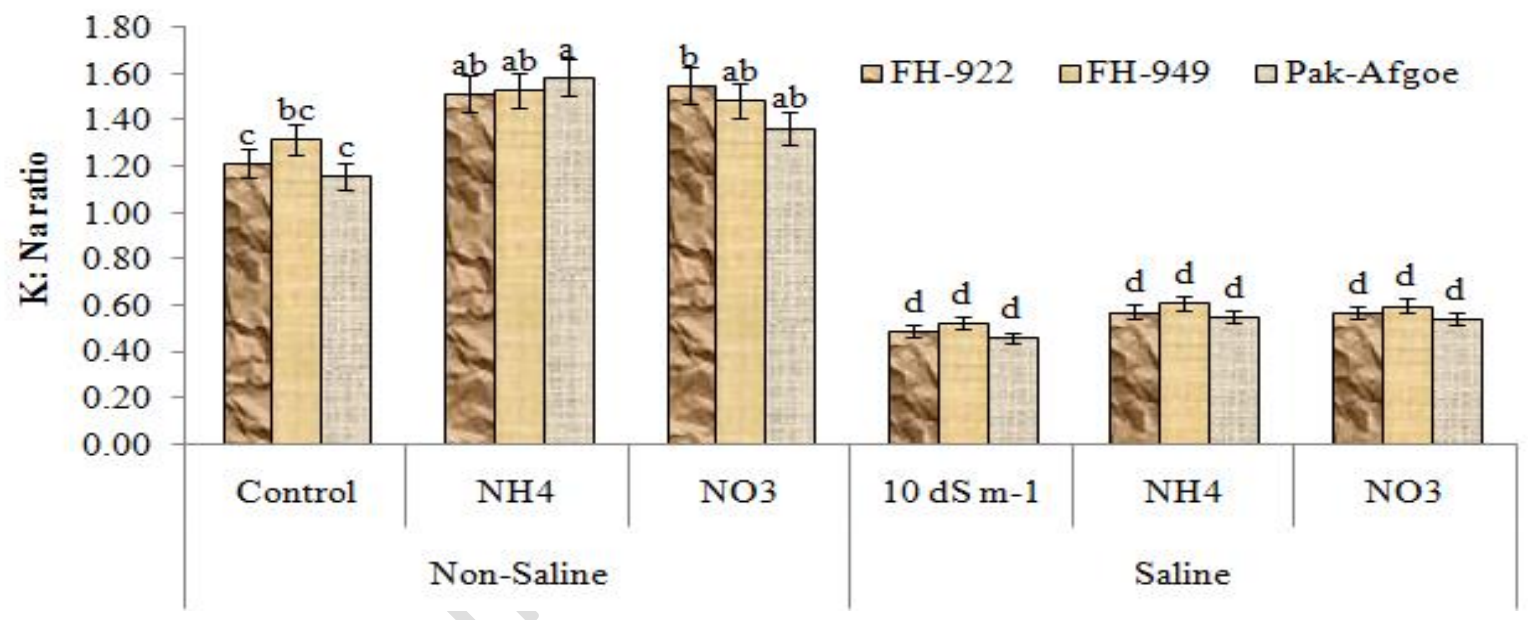

Figure 5. Effect of $\mathrm{NO}_{3}-\mathrm{Nand} \mathrm{NH}_{4}-\mathrm{N}$ on maize hybrids potassium to sodium ratio
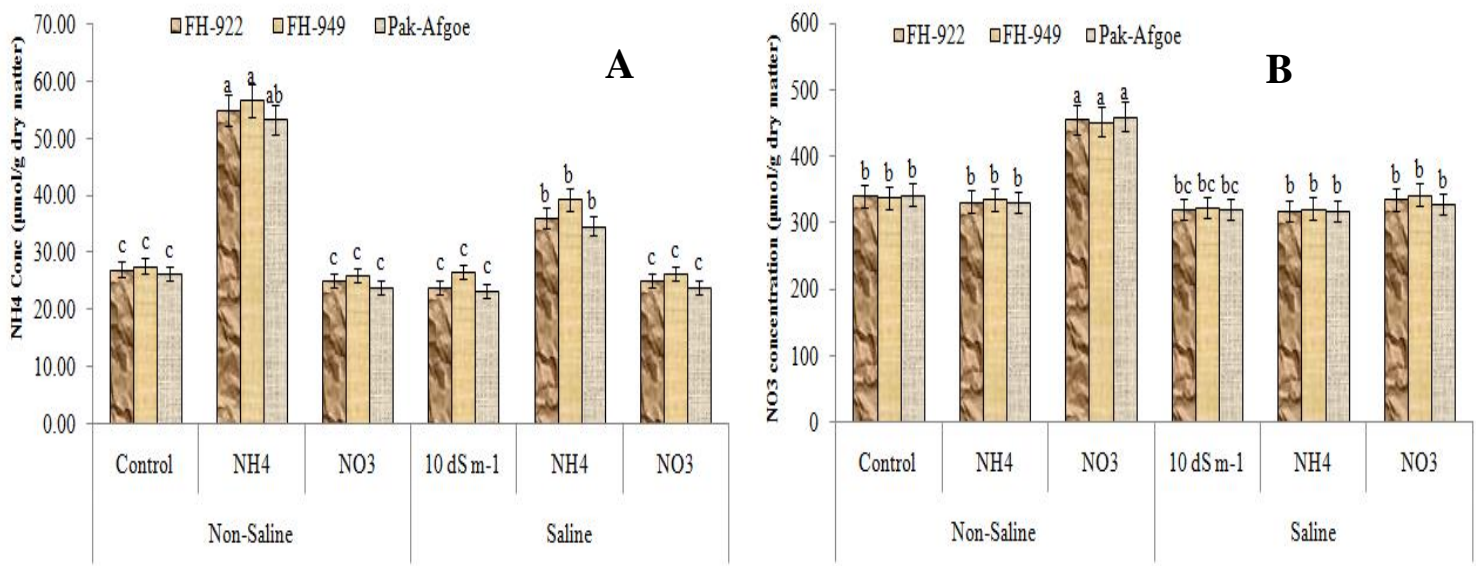

Figure 6. Effect of $\mathrm{NO}_{3}-\mathrm{N}$ and $\mathrm{NH}_{4}-\mathrm{Non} \mathrm{A}$ ) $\mathrm{NH}_{4}$ concentration $\mathrm{B}$ ) $\mathrm{NO}_{3}$ concentration of maize hybrids 


\section{Conclusion}

In Current study, it was observed that $\mathrm{NH}_{4}{ }^{+}$ $-\mathrm{N}$ increased the maize hybrids growth in the term of fresh and dry biomass, plant height, leaf area, crude protein, $\mathrm{K}$ concentration and $\mathrm{K}: \mathrm{Na}$ ratio. Furthermore, salt stress either without application of any $\mathrm{N}$ source adversely affected the growth of forage maize. The maize plants fertilized with nitrogen application as $\mathrm{NH}_{4}$ form produced significantly higher forage yields as it has a key role in acidification of root zone which reduced the alkaline conditions and increased the nutrient availability. Comparing the genotypic performance of maize hybrids, FH-949proved to be the best genotype for fodder production. The adaptation of such approaches in future under saline conditions are helpful for getting good forage yield in saline agriculture especially in calcareous and arid and semiarid regions.

\section{Authors' contributions}

Conceived and designed the experiments: M Ibrahim \& M Jan, Performed the experiments: MM Maqbool \& B Tariq, Analyzed the data: M Nadeem \& A Rauf, Contributed reagents/ materials/ analysis tools and wrote the paper: AN Abbas.

\section{Acknowledgement}

The author wish to thanks Higher Education Commission (HEC) Islamabad, Pakistan for the provisions of funds from HEC funded SRGP Project.

\section{References}

1. Irshad M, Yamamoto S, Eneji AE, Endo T \& Honna T (2002). Urea and manure effect on growth and mineral contents of under saline conditions. J Plant Nutr 25(1): 189200.

2. Barbary SM (2017). On- farm soil management practices for improving soil properties and productivity of rice and wheat under salt affected soil at North Delta, Egypt. J Soil Sci 57(4): 445-453.

3. FAO (2010). FAO Land and plant nutrition management service. http://www.fao.org.

4. Qadir M \& Oster J (2004). Crop and irrigation management strategies for salinesodic soils and waters aimed at environmentally sustainable agriculture. Sci Tot Environ 323: 1-19.

5. Alla MMN \& Hassan NM (2020). Nitrogen alleviates $\mathrm{NaCl}$ toxicity in maize seedlings by regulating photosynthetic activity and ROS homeostasis. Acta Physiol Planta 42(6): 1-10.

6. GOP (Govt. of Pakistan) (2016). Pakistan Bureau of statistics. Natural Resources Division, Pakistan Agricultural Research Council, Islamabad.

7. Ibrahim M, Ayub M, Tanveer A \& Yaseen $M$ (2012). Forage quality of maize and legumes asmonocultures and mixtures at different seed ratios. $J$ Anim Plant Sci 22(4): 987-992.

8. Ibrahim M, Tahir M, Noorka IR, Maqbool M, Hussain M, Bashir SMA, Qaisrani TB, Safde E, Lauriault LM (2016). Effect of seed properties on growth and forage yield of maize sown alone and in mixture with three legumes. Inter J Agric Appl Sci 8(1).

9. Ayub M, Nadeem MA, Sharar MS \& Mahmood N (2002). Response of maize (Zea mays L.) fodder to different levels of nitrogen and phosphorus. Asian J Plant Sci 1(4): 352-354.

10. Iptas S \& Acar AA (2006). Effects of hybrid and row spacing on maize forage yield and quality. Plant Soil Environ 52(11): 515-522.

11. Ullah MA, Anwar M \& Rana S (2010). Effect of nitrogen fertilization and harvesting intervals on the yield and forage quality of elephant grass (Pennisetum purpureum) under mesic climate of pothowar plateau. Pak J Agric Sci 47: 231234.

12. Arif M, Jan MT, Khan NU, Akbar HA, Khan SA, Khan MJ \& Iqbal A (2010). Impact of plant populations and nitrogen levels on maize. Pak J Bot 42(6): 39073913.

13. Cheema MA, Farhad W, Saleem MF, Khan HZ, Munir A, Wahid MA \& Hammad HM (2010). Nitrogen management strategies for sustainable maize production. Crop Environ 1(1): 49-52.

14. Sabir M, Hanafi MM, Malik M and Aziz T, Zia-ur-Rehman T, Ahmad M \& Shahid M (2013). Differential effect of nitrogen forms on physiological parameters and micronutrient concentration in maize ('Zea mays' L.). Aust J Crop Sci 7(12): 1836. 
15. Zhou Y, Zhang Y, Wang X, Cui J, Xia X, Shi K \& Yu J (2011). Effects of nitrogen form on growth, $\mathrm{CO}_{2}$ assimilation, chlorophyll fluorescence, and photosynthetic electron allocation in cucumber and rice plant. Biomed Biotechnol 12: 126-134.

16. Xin Z, Mei G, Shiqing L Shengxiu L \& Zongsuo L (2011). Growth, water status and photosynthesis in two maize (Zea mays L.) Cultivars as affected by supplied nitrogen form and drought stress. Pak J Bot 43: 1995-2001.

17. Lugert I, Gerendas J, Bruech H \& Sattelmacher B (2001). Influence of N form on growth and water status of tomato plants. In: Horst WJ (ed) Plant NutritionFood Security and Sustainability of AgoEcosystems. Kluwer Academic Publishers, Dordrecht.

18. US Salinity Laboratory Staff (1954). Handbook 60, US Government printing office. Washington, DC. Van Genuchten MTh 1987 Res. Report.

19. Hu Y, Burucs Z \& Schmidhalter U, (2008). Effect of foliar fertilization application on the growth and mineral nutrient content of maize seedlings under drought and salinity. Soil Sci Plant Nutri 54: 133-141.

20. Jones JRJ \& Case VW (1990). Sampling, handling, and analyzing plant tissue samples. In Soil Testing and Plant Analysis, RL Westerman (ed.). SSSA. Madison, WI, USA. pp. 389-428.

21. McGill W \& Figueiredo C (1993). Total nitrogen. Soil sampling and methods of analysis. Lewis Publ, Boca Raton, FL, 201211.

22. Steel RGD, Torrie JH \& Dickey GH, (1997). Principles and Procedures of Statistics. A Bio-Matrical Approach, $3^{\text {rd }}$ edition. McGraw Hill Book Co, Inc New York. pp. 400-428.

23. Hessini K, Ben Hamed K, Gandour M, Mejri M, Abdelly C \& Cruz C (2013). Ammonium nutrition in the halophyte Spartina alterniflora under salt stress: evidence for a priming effect of ammonium. Plant Soil 370: 163-173.

24. Hessini K, Kronzucker HJ, Abdelly C \& Cruz C (2017). Drought stress obliterates the preference for ammonium as an $\mathrm{N}$ source in the $\mathrm{C}_{4}$ plant Spartina alterniflora. J Plant Physiol 213: 98-107.
25. Hessini K, Lachaal, Cruz MC \& Soltani A (2009). Role of ammonium to limit nitrate accumulation and to increase water economy in Wild Swiss chard. J Plant Nutr 32: 821-836.

26. Ashraf M, Shahzad S, Imtiaz M, Rizwan M, Arif MS \& Kausa R (2018). Nitrogen nutrition and adaptation of glycophytes to saline environment: a review. Archives Agron Soil Sci 64(9): 1181-1206.

27. Collado MB, Arturi MJ, Aulicino MB \& Molina MC (2010). Identification of salt tolerance in seedling of maize (Zea mays L.) with the cell membrane stability trait. Inter Res J Plant Sci 1(5): 126-132.

28. Kaya C, Demir S, Sonmez O \& Ashraf M (2013). Regulation of growth and some key physiological processes in salt-stressed maize (Zea mays L.) plants by exogenous application of asparagine and glycerol. Acta Bot Croat 72(1): 157-168.

29. Ibrahim M, Ayub M, Maqbool MM, Nadeem SM, Haq TU, Hussain S, Ali A \& Lauriault LM, (2014). Forage yield components of irrigated maize-legume mixtures at varied seed ratios. Field Crops Res 169: 140-144.

30. Asim M, Zamir S, Hussain M, Hassan N, Mohi-Ud-Din MS \& Nasir M (2017). Performance of sorghum cultivar in terms of forage yield and quality under varying planting patterns. Inter J Sci Eng Res 8(5): 435-436.

31. Karasu A, Oz M, Bayram G \& Turgut I (2009). The effect of nitrogen levels on forage yield and some attributes in some hybrid corn (Zea mays indentata Sturt.) cultivars sown as second crop for silage corn. Afri J Agric Res 4: 166-170.

32. Ahmad W, Ahmad A, Zamir M, Afzal M, Mohsin A, Khalid F \& Gillani S (2012). Qualitative and quantitative response of forage maize cultivars to sowing methods under subtropical conditions. J Ani Plant Sci 22: 318-323.

33. Verma NK, Pandey BK, Singh UP \& Lodhi MD (2012). Effect of sowing dates in relation to integrated nitrogen management on growth, yield and quality of rabi maize. J Ani Plant Sci 22: 324-329.34.

34. Ashraf M \& Harris PJC (2013). Photosynthesis under stressful environments: An overview. Photosynthetica 2: 163-190. 
35. Ahmad M, Zahir ZA, Jamil M, Nazli F, Latif M, Akhtar MF (2014). Integrated use of plant growth promoting rhizobacteria, biogas slurry and chemical nitrogen for sustainable production of maize under saltaffected conditions. Pak J Bot 46(1): 375382.

36. O'Neill, BF, Zangerl AR, DeLucia EH, Casteel C, Zavala JA \& Berenbaum MR (2011). Leaf temperature of soybean grown under elevated $\mathrm{CO}_{2}$ increases Aphis glycines (Hemiptera: Aphididae) population growth. Insect Sci 00: 1-7.

37. Slama I, Abdelly C, Bouchereau A, Flowers T \& Savouré A (2015). Diversity, distribution and roles of osmoprotective compounds accumulated in halophytes under abiotic stress. Ann Bot 115(3): 433447.

38. Rahneshan Z, Nasibi F \& Moghadam AA (2018). Effects of salinity stress on some growth, physiological, biochemical parameters and nutrients in two pistachio (Pistacia vera L.) rootstocks. J Plant Interact 13(1): 73-82.

39. Bybordi A (2012). Effect of different ratios of nitrate and ammonium on photosynthesis, and fatty acid composition of canola under saline conditions. Inter $J$ Agric Crop Sci 4(10): 622-626.

40. Flowers TJ, Munns R \& Colmer TD (2015). Sodium chloride toxicity and the cellular basis of salt tolerance in halophytes. Ann Bot 115: 419-431.

41. Abid M, Qayyum A, Dasti A \& Wajid RR (2001). Effect of salinity and SAR of irrigation water on yield physiological growth parameters of maize and properties of soil. J Res (Sci) Bahaud din Zakaryia Uni Mul Pak 12(1): 26-33.

42. Demidchik V \& Maathuis FJM (2007). Physiological roles of nonselective cation channels in plants: from salt stress to signalling and development. New Phytol175: 387-404.
43. Genc Y, Oldach K, Taylor J \& Lyons GH (2016). Uncoupling of sodium and chloride to assist breeding for salinity in crops. New Phytol 210: 145-156.

44. Alvarez-Aragon R, Haro R, Benito B \& Rodriguez-Navarro A (2016). Salt intolerance in Arabidopsis: shoot and root sodium toxicity, and inhibition by sodiumplus-potassium over accumulation. Planta 243: 97-114.

45. Ferchichi S, Hessini K, Dell'Aversana E, Amelia L, Woodrow P, Ciarmiello F, Fuggi A \& Carillo P (2018). Hordeum vulgare and Hordeum maritimum respond to extended salinity stress displaying different temporal accumulation pattern of metabolites. Funct. Plant Biol.

46. Ali A, Basra SMA, Iqbal J, Hussain S, Subhani MN, Sarwar M \& Ahmad M (2012). Augmenting the salt tolerance in wheat (Triticum aestivum) through exogenously applied silicon. Afric $J$ Biotech 11(3): 642-649.

47. Azooz MM, Ismail AM \& Abou Elhamd FM (2009) Growth, lipid peroxidation antioxidant enzyme activities as a selection criterion for the salt tolerance of maize cultivars grown under salinity stress. Inter J Agric Biol 11(1): 21-26.

48. Ehlting B, Dluzniewsk P, Dietrich H, Selle A, Teuber M, Hänsch R, Nehls U, Polle A, Schnitzler JP, Rennenberg H \& Gessler A (2007). Interaction of nitrogen nutrition and salinity in grey poplar (Populus tremula $\times$ alba). Plant Cell Environ 30: 796-811.

49. Gok M, Dogan K \& Coskan A (2006). Effects of divers organic substrate application on denitrification and soil respiration under different plant vegetation in Çukurova region. International Symposium on Water and Land Management for Sustainable Irrigated Agriculture. April 4-8, 2006, AdanaTurkey. 